\title{
PKM PEMBERDAYAAN KADER POSYANDU DALAM PENGGUNAAN APLIKASI ANDROID STATUS GIZI BALITA
}

\author{
Chusnul Zulaika ${ }^{1}$, Ambar Dwi Erawati ${ }^{2}$, Mona Tiorina Manurung ${ }^{3}$ \\ ${ }^{1,2,3)}$ Fakultas Keperawatan Bisnis dan Tehnologi, Universitas Widya Husada Semarang \\ e-mail: chusnul.zulaika@gmail.com
}

\begin{abstract}
Abstrak
Status gizi merupakan keadaan tubuh sebagai akibat interaksi antara asupan energi dan protein serta zat-zat gizi esensial lainnya dengan keadaan kesehatan tubuh. Ketidakseimbangan (kelebihan atau kekurangan) antara zat gizi dengan kebutuhan tubuh akan menyebabkan kelainan patologi bagi tubuh manusia. Keadaan demikian disebut dengan malnutrition (gizi salah atau kelainan gizi). Secara umum bentuk kelainan gizi digolongkan menjadi 2 yaitu overnutrition (kelebihan gizi) dan under nutrition (kekurangan gizi). Permasalahan yang ditemukan di RW 09 adalah adanya pandemi Covid ini terdapat $62 \%$ ibu yang memiliki balita takut membawa balitanya ke posyandu walaupun di posyandu sudah diterapkan protokol kesehatan. Posyandu yang dilaksanakan hanya dihadiri 36 balita dan sisanya tidak hadir di posyandu. Salah satu upaya yang dapat dilakukan untuk memotivasi ibu supaya mau mengajak balitanya ke posyandu adalah dengan melaksanakan posyandu sesuai dengan protokol Covid dan juga mendampingi ibu untuk menggunakan aplikasi status gizi supaya ibu yang mempunyai balita bisa memantau status gizi balita di rumah setiap bulannya.
\end{abstract}

Kata kunci: Aplikasi Android Status Gizi Balita, Kader Posyandu, Pemberdayaan

\begin{abstract}
Nutritional status is the state of the body as a result of the interaction between energy and protein intake and other essential nutrients and the state of the body's health. An imbalance (excess or deficiency) between nutrients and body needs will cause pathological abnormalities in the human body. This condition is called malnutrition (malnutrition or malnutrition). In general, the form of nutritional disorders is classified into 2, namely overnutrition (excess nutrition) and under nutrition (malnutrition). The problem found in RW 09 was that there was a covid pandemic, $62 \%$ of mothers with toddlers were afraid to bring their children to posyandu even though health protocols had been implemented at the posyandu. The posyandu that was implemented was only attended by 36 toddlers and the rest were not present at the posyandu. One of the efforts that can be made to motivate mothers to want to invite their children to the posyandu is to implement a posyandu according to the Covid protocol and also assist mothers to use the nutritional status application so that mothers with toddlers can monitor the nutritional status of toddlers at home every month
\end{abstract}

Keywords: Android Application Of Nutritional Status Of Toddlers, Posyandu Cadres, Empowerment

\section{PENDAHULUAN}

Status gizi merupakan keadaan tubuh sebagai akibat interaksi antara asupan energi dan protein serta zat-zat gizi esensial lainnya dengan keadaan kesehatan tubuh. Ketidakseimbangan (kelebihan atau kekurangan) antara zat gizi dengan kebutuhan tubuh akan menyebabkan kelainan patologi bagi tubuh manusia. Keadaan demikian disebut dengan malnutrition (gizi salah atau kelainan gizi). Secara umum bentuk kelainan gizi digolongkan menjadi 2 yaitu overnutrition (kelebihan gizi) dan under nutrition (kekurangan gizi) (Hidayati Tutik,dkk, 2019).

Untuk mencegah terjadinya berbagai gangguan gizi dan masalah psikososial, diperlukan adanya perilaku penunjang dari para orang tua, ibu atau pengasuh dalam keluarganya untuk selalu memberikan makanan dengan gizi seimbang kepada balitanya. Perlu diketahui bahwa yang dimaksud dengan gizi seimbang merupakan makanan yang dikonsumsi balita dalam satu hari yang beraneka ragam dan mengandung zat tenaga, zat pembangun dan zat pengatur sesuai dengan 
kebutuhan tubuhnya. Keadaan ini tercermin dari derajat kesehatan dan tumbuh kembang balita yang optimal ( Adriani, M, 2016).

Tujuan kegiatan ini agar kader mengetahui tentang aplikasi status gizi. Kegiatan ini dilaksanakan di RW 09 Kelurahan Gondoriyo Kecamatan Ngaliyan. Kegiatan ini bisa digunakan untuk memudahkan ibu ibu yang mempunyai balita supaya bisa memantau status gizi balitanya setiap bulan.

\section{METODE}

Tahapan yang dilakukan untuk kegiatan ini adalah tahap persiapan dan tahap pelaksanaan. Tahap persiapan yang dilaksanakan adalah mengajukan ijin ke ketua RW dan ketua pokja 4, persiapan tempat, persiapan materi yang akan diberikan. Tahap pelaksanaan yaitu sebelum kegiatan dimulai, kader posyandu diminta untuk mengisi kuesioner pretest untuk mengukur sejauh mana pemahaman kader tentang aplikasi status gizi balita. Kemudian diberikan penyuluhan tentang penggunaan aplikasi status gizi balita. Setelah diberikan penyuluhan di akhir kegiatan diberikan post test supaya bisa mengetahui ada atau tidaknya peningkatan pengetahuan tentang penggunaan aplikasi status gizi balita.

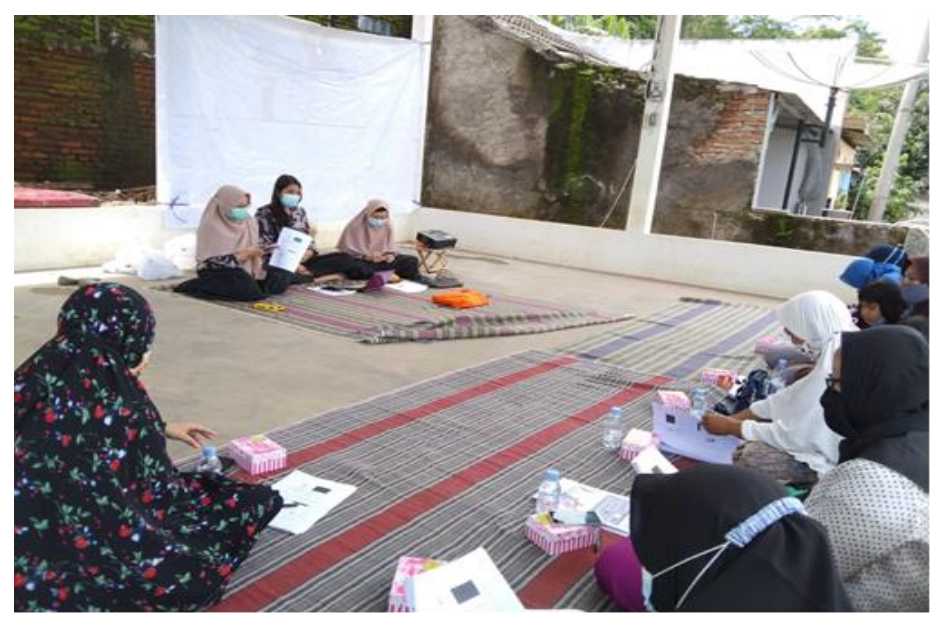

Gambar 1. Pemberian Materi Aplikasi status Gizi kepada para Kader Posyandu

\section{HASIL DAN PEMBAHASAN}

Tabel 1. Perbandingan skor total jawaban pre test dan post test

Paired Samples Test

\begin{tabular}{|c|c|c|c|c|c|c|c|c|c|}
\hline & \multicolumn{5}{|c|}{ Paired Differences } & \multirow[b]{3}{*}{$\mathrm{t}$} & \multirow[b]{3}{*}{ df } & \multirow{3}{*}{$\begin{array}{l}\text { Sig. (2- } \\
\text { tailed) }\end{array}$} \\
\hline & & \multirow[b]{2}{*}{ Mean } & \multirow{2}{*}{$\begin{array}{c}\text { Std. } \\
\text { Deviation }\end{array}$} & \multirow{2}{*}{$\begin{array}{c}\text { Std. Error } \\
\text { Mean }\end{array}$} & \multicolumn{2}{|c|}{$\begin{array}{c}95 \% \text { Confidence } \\
\text { Interval of the } \\
\text { Difference }\end{array}$} & & & \\
\hline & & & & & Lower & Upper & & & \\
\hline Pair 1 & $\begin{array}{l}\text { total_prete } \\
\text { st_aplikasi } \\
- \\
\text { posttest_a } \\
\text { plikasistat } \\
\text { usgizi }\end{array}$ & -1.714 & 1.380 & .522 & -2.991 & -.438 & -3.286 & 6 & .017 \\
\hline
\end{tabular}

Berdasarkan tabel 1 didapatkan hasil uji t berpasangan dengan nilai significancy 0.017 $(\mathrm{p}<0.05)$, yang artinya adalah terdapat perbedaan rerata yang signifikan secara statistik antara variabel skor total jawaban pada pre test dan post-test. Metode pendampingan yang dilakukan 
dipilih sesuai dengan tujuan yang akan dicapai. Menurut Notoatmojo 2012 menunjukkan bahwa untuk merubah perilaku perlu dipilih metode yang tepat. Metode untuk mengubah pengetahuan dapat menggunakan metode ceramah, tugas baca, panel dan konseling. Hal ini sesuai dengan penelitian yang dilakukan oleh Ni'ma Nazilia bahwa terdapat peningkatan pengetahuan setelah diberikan aplikasi Emas dengan peningkatan $84,35 \%$ atau dapat dikatakan baik. Peningkatan tersebut dikarenakan informasi yang diterima oleh subjjek dapat dipahami dan diserap dengan baik (Nazilia, N, 2020)

\section{SIMPULAN}

Kegiatan pengabdian kepada masyarakat mengenai aplikasi status gizi balita sudah terlaksana dengan baik. Dari hasil pre test dan post test dapat disimpulkan adanya peningkatkan pengetahuan aplikasi status gizi balita.

\section{SARAN}

Diharapkan seluruh kader untuk tetap memantau status gizi balita walupun dalam masa pandemi dengan tetap menjaga protokol kesehatan.

\section{UCAPAN TERIMA KASIH}

Ucapan terimakasih kami sampaikan kepada Rektor Universitas Widya Husada Semarang dan LPPM Universitas Widya Husada Semarang yang telah memberikan arahan dan memberikan pendanaan kegiatan pengabdian masyarakat ini

\section{DAFTAR PUSTAKA}

Hidayati, Tutik dkk. (2019). Pendamping Gizi Pada Balita. Sleman:CV Budi Utama

Adriani, M dan Wiriatmadi, B. (2016). Peranan Gizi dalam Siklus Kehidupan. Jakarta : Prenadamedia Group

Aplikasi Status Gizi Balita

https://play.google.com/store/apps/details?id=com.fbasegizi.statusgizi\&hl=in\&gl=US. Diunduh pada tanggal 2 Januari 2021

Nazilia N, Iqbal M. (2020). Peningkatan Pengetahuan Ibu tentang Gizi Untuk Mengatasi Gizi Buruk Pada Anak Balita Dengan Aplikasi "Anak Sehat Makan Sehat (EMAS)". http://journal.binawan.ac.id/JAKAGI/article/view/120/114.

Notoatmodjo, Soekidjo. 2012. Promosi Kesehatan dan Perilaku Kesehatan. Jakarta : PT Rineka Cipta 